\title{
卷酘言
}

\section{Integrated Chemical Synthesizer}

\author{
京都大学大学院工学研究科教授 吉 田 潤 -
}

Jun-ichi Yoshida

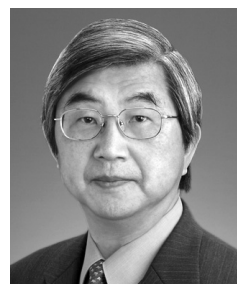

1994 年に Allen J. Bard が“Integrated Chemical Systems. A Chemical Approach to Nanotechnology" と いうタイトルの本を著している。1987 年に行った講義 (Baker Lectures at Cornell University) を元にしたとあ るが，内容は現在でも非常に興味深く示唆に富んでお り, 先見性の高い本である。この本の Future Integrated Chemical Systems という最終章に, integrated chemical synthesizers が簡単なスキーム入りで取り上 げられている。これは, an ICS synthesizer would consist of small (millimeter- to micrometer-sized) reactors, designed for a particular application, along with associated ICS devices for moving reactant and product streams (pumps), mixing reactants, analyzing streams, and separating products. (ICS は integrated chemical system の略）と定義されている。Bard は，約 20 年前 にすでに，現在のフロー・マイクロリアクターシステム を予言していたのである。とくに興味深いのは，the use of serial reactors to allow controlled sequential reactions of intermediates というくだりである。不安定 な中間体を発生させ，それが分解する前にフロー系で次 の反応器に移動させ望む反応に利用するという概念が, すでにここに述べられている。実は，このようなアイデ アは多くの化学者の中にあったのかも知れないが，それ を具体的に実現する方法が今までなかったのではないか とも考えられる。しかし，この約 10 年間でフロー・マ イクロリアクターが実用的に使えるようになり，ミリ秒 オーダーの滞留時間で活性中間体を合成反応に活用でき るようになった。つまり，Bardのアイデアが実現可能 な時代になってきたといえる。

平成 21 年度から始まった新学術領域研究「反応集積 化の合成化学 革新的手法の開拓と有機物質創成への展 開」は，まさにこのアイデアを実現し，実際の合成に展
開しようとするものである。集積化により短寿命活性種 の制御と活用が容易になるという特長を生かして, 従来 達成困難であった分子変換法を構築するとともに, 実際 の生物活性物質合成や機能性物質合成への展開を行い, 有機合成化学における新領域の構築をめざしている。本 領域では，同一時空間集積化（ドミノ反応，タンデム反 応など), 時間的集積化 (ワンポット反応)，拉よび空間 的集積化など多様な反応集積化法を対象としているが, とくに空間的集積化は，フロー・マイクロリアクターの 特長を生かして, 不安定活性種を中間体とする反応集積 化を目指している。

現在, フロー合成という有機合成化学の新しい潮流 が，世界で起こりつつある。たとえば，2005 年から 2009 年にかけてヨーロッパで IMPULSE (Integrated Multiscale Process Units with Locally Structured Elements) プロジェクトが行われた。また，2007年から 10 年計画で多段階フロー合成をめざした Novartis-MIT の ビッグプロジェクトも始まっている。ここには，MIT の有機合成化学者も参加しており，今までヨーロッパと 日本が中心であったこの分野に，いよいよ米国も本格的 に参入しはじめた。

これまで有機合成化学者は, 実験室の反応器として, ほとんどフラスコしか利用することができないという状 況であったが，反応環境を格段に精密制御できるフ ロー・マイクロリアクターという新しい反応器が手に入 るようになった。その利用によって，今まで実現できな かった分子変換が可能になり, 新しい生物活性物質や機 能性物質の創成が可能になるに違いない。従来のフラス コの制約から解放された新しい有機合成化学の領域を開 く時がきたといえる。

(2010 年 4 月 5 日受理) 